\title{
Unbalanced Growth in the Labourscape: explaining regional employment divergence
}

September 2021

This is a draft version of a paper that has been accepted for publication in a forthcoming issue of Regional Studies (DOI: 10.1080/00343404.2021.1972958).

Robert Sobyra*, Thomas Sigler and Elin Charles-Edwards

Department of Earth and Environmental Sciences

University of Queensland

* Corresponding author: r.sobyra@uq.edu.au

Keywords: Regional Divergence, Regional Growth, Shift-Share Analysis, Employment Growth

JEL Codes: R1 - General Regional Economics < R - Urban, Rural, Regional, Real Estate, and Transportation Economics 


\begin{abstract}
This paper investigates the role of human capital in explaining divergent employment growth within advanced economies. The paper adds a spatial dimension to William J. Baumol's theory of 'unbalanced growth' by linking it with the concept of 'job polarisation.' We develop a theory of 'geographical unbalanced growth' that explains divergent employment trajectories in terms of skill restructuring. The theory is operationalised via a novel shift-share extension, which is applied to Australian data. We find evidence of ongoing regional divergence and for our proposed mechanism. The findings reinforce the importance of active policies to attract high-skill jobs to nonmetropolitan regions.
\end{abstract}




\section{Introduction}

According to neoclassical economic theory, regional economic outcomes should converge over time. The basic logic is that, as developed regions become overdeveloped, diseconomies arise that make underdeveloped regions more attractive to factor inputs, which are assumed to be mobile, leading to equilibrium over time (Barro and Sala-i-Martin, 1995; Stimson et al., 2006). While it seemed for a time that this prediction may come to pass within many advanced economies, the notion that regions within national economies generally converge toward an equilibrium of outcomes is no longer credible. Indeed, the empirical record reveals a general pattern of regional divergence across advanced economies since the 1990s, albeit with a considerable degree of unevenness (Gabe, 2017; Moretti, 2012; Brakman and van Marrewijk, 2008; Krätke, 2007; Martin, 2005; Martin et al. 2016; Gardiner et al., 2013; Corliss and Lewis, 2014). A new geography of jobs seems to have emerged whereby non-metropolitan areas are falling behind major metropolitan centres in terms of employment and income growth (Sorenson, 2000; Sassen, 2001; McCann, 2008; Pike et al., 2017; Scott and Storper, 2015; Glaeser, 2011).

While the concentration of economic activity in and around major metropolitan cities is one of the most evident empirical regularities of our time, explanations for this pattern are less definitive. Early suggestions that metropolisation is simply a matter of urbanisation economies and cultural agglomeration (Bell, 1973) have been found to be problematic, forcing many early proponents to reconsider their narratives (Florida, 2017; Glaeser and Saiz, 2003).

That said, the empirics seem to indicate a key role for human capital in shaping divergent growth trajectories. The 'skilled cities' literature, for example, observes that cities with more educated residents have grown faster than those with less (Simon, 1998; Simon and Nardinelli, 2002; Glaeser and Berry, 2006; Scott, 2009; Chadwick et al., 2008; Südekum, 2010; Moretti, 2013; Sunley et al., 2019). The dominant explanation for this observation is that deindustrialisation is increasing the demand for higher-level, cognitive skills, while decreasing the demand for physical skills. Cities with greater concentrations of this type of human capital are therefore most likely to experience the strongest economic growth, and these localities tend to be major metropolitan conurbations (Gabe, 2017; Scott, 2009).

This paper aims to build upon this literature by proposing a mechanism whereby structural patterns of economic change translate into spatial patterns of regional divergence. Specifically, we resurrect Baumol's (1967) theory of unbalanced growth and link it with another key feature of advanced capitalism-job polarisation-to argue that the intertwining of industrial and skill restructurings plays an important role in shaping regional employment trajectories. The first half of this paper develops these ideas into a coherent theoretical framework, which we term 'geographical unbalanced growth.' The theory predicts that economic restructuring explains contemporary regional divergence when the former is conceived as a function of changes in both industry and skill composition. In the second half of the paper, we develop a novel extension of the shiftshare framework to operationalise the theory and apply it to recent Australian data. 


\section{Job Polarisation and Unbalanced Growth}

Job polarisation describes a structural decline in middle-skilled occupations accompanied by a systematic and pervasive deskilling of the workforce that has pushed middle-skilled workers into lower-wage occupations (Weil, 2014; Autor and Dorn, 2013). It is a process whereby the demand for middle-skilled labour (such as manufacturing and clerical workers) decreases, while the demand for high-skilled workers (such as health and engineering professionals) and low-skilled workers (such as personal service and sales workers) increases (Goos and Manning, 2007). Job polarisation has been robustly identified in the US (Autor et al., 2006), European (Goos et al., 2009) and Australian economies (Coelli and Borland, 2016).

Explaining job polarisation has been a key concern of labour economists in recent years. Bárány and Siegel (2018) find that job polarisation is largely explained by the contraction of 'old' industries such as manufacturing, agriculture and mining, with a concomitant increase in low-skilled services and high-skilled services. Technology seems to have played the key role in this trend by replacing many of the routine tasks performed by middle-skilled labour (Dao et al., 2017; Goos et al. 2014). While persuasive, there is a sense in which these technology-driven explanations of job polarisation are somewhat superficial, highlighting only the most proximate variable in a causal chain that runs far deeper. The role of economic restructuring, particularly the shift toward new macroeconomic regimes, rarely receives more than a cursory discussion in the literature.

We propose that Baumol's (1967) theory of 'unbalanced growth' provides an entry point to a deeper understanding of job polarisation. Drawing on ideas about structural economic change that can be traced back to Neisser (1942), Baumol (1967) argues that a breakdown in the relationship between productivity and employment growth lies at the core of the job polarising trend. Salter (1960) was among the first to articulate the relationship between productivity and employment. The basic logic is that productivity improvements drive prices lower, and that those lower prices create new demand by drawing new buyers into the market. While this is an inherently labourreducing process, the increased demand arising from lower prices generates enough new jobs to offset any labour displaced by the more productive production. This in turn incentivises further investment, leading to a virtuous cycle of increasing gains in productivity, employment and incomes.

For many years, this theory was so robust to empirical examination that it came to be considered a 'stylised fact' of capitalism. Yet the virtuous relationship between productivity, employment and incomes has broken-down in most advanced economies over recent decades (OECD, 2018; Appelbaum and Schettkat, 1995). For mainstream economists, this reversal in the employment effects of productivity growth is one of the defining puzzles of contemporary capitalist development (Krugman, 1994; OECD, 2018). Yet Baumol's (1967) theory of 'unbalanced growth' presaged a breakdown in the productivity-employment nexus long before it became evident. Baumol's (1967) argument hinges on the observation that markets face diminishing price-elasticities of demand-that is, over time, price reductions tend to create less-and-less new demand.

In short, unbalanced growth means that, over time, firms face increasingly insufficient aggregate demand to justify enough new employment to offset the labour savings achieved through productivity gains. The aggregate effect of this dynamic is that industries with high productivity growth, which Baumol (1967) calls 'progressive,' tend to shed jobs without creating sufficient offsetting new employment. This displaced 
labour then has no alternative but to find employment in industries with low productivity growth, which Baumol (1967) calls 'lagging.' Over time, therefore, the lagging sector comes to assume the role as the main source of employment growth. While unbalanced growth theory dates to the 1960s, it has found much contemporary empirical support (Hartwig and Krämer, 2019; Storm, 2017; Nordhaus, 2008; Schettkat, 2007; Blien and Sanner, 2006).

It can be readily seen how the dynamics of unbalanced growth may underpin the polarisation of labour markets. The gravitation of new employment toward the lagging sector will tend to shunt an increasing share of employment into lower-skill jobs, because these jobs tend to dominate less-productive industries (Goos et al., 2009). Meanwhile, any employment that is created by the progressive sector is likely to be higher-skill, owing to the well-established link between more productive production processes and higher skill content (Autor et al., 2003). Thus, in an environment of unbalanced growth, we would expect to observe a trend toward job polarisation - that is, growth in both low- and high-skilled jobs, and a contraction in the middle.

We now turn to our core concern: the geographical consequences of these dynamics.

\section{Geographical Unbalanced Growth}

That changes in the structure of economies lead to changes in the geographies of economic activity is a touchstone principle of economic geography (Harvey, 1982; Massey, 1979). As the requirements of production change in response to the evolution of global capitalism, so does the relevance to production of any given form of spatial differentiation. Geography and economy thus coevolve in what Soja (1980) calls the 'socio-spatial dialectic.' This paper has so far highlighted a particular change in the requirements of production that has occurred within advanced economies over the last several decades - namely, the tendency for unbalanced growth to reduce the demand for middle-skilled workers, while increasing the demand for both low- and high-skilled workers. In what follows, we complete the dialectic with a mechanism by which job polarisation interacts with employment geographies to generate regional divergence.

The theory rests on two assumptions: first, that changes in middle- and low-skill employment are likely to affect metropolitan and non-metropolitan regions relatively uniformly, and; second, that changes at the high end of the skill spectrum, by contrast, are likely to be non-random, favouring large metropolitan conurbations over smaller regions. There is no immediately obvious reason why changes in middle- and lowskilled employment would be geographically differentiated in any systematic way. Analysis of Labour Force Survey data indicates that a grouping of low- and middle-skill occupations grew at similar rates within Australia's capital cities and the rest of the country $\left(30.3 \%\right.$ and $32.6 \%$, respectively). ${ }^{\mathrm{i}}$

By contrast, it seems clear that high-skill employment growth would tend to skew toward metropolitan centres. This outcome is supported empirically by the 'skilled cites' literature, which finds that large cities tend to attract an outsized share of high-skill employment growth (Simon, 1998; Simon and Nardinelli, 2002; Glaeser and Berry, 2006; Scott, 2009; Chadwick et al., 2008; Südekum, 2010; Moretti, 2013; Sunley et al., 2019).

A metropolitan bias in high-skill employment growth is also supported by a body of research that finds new employment tends to collect around existing concentrations of workers, rather than firms and industries (Simon, 2004; Storper and Scott, 2009; 
Moretti, 2013; Glaeser and Berry, 2006; Simon and Nardinelli, 2002; Faggian and McCann, 2009). Agglomeration processes seem to be driven more by relatedness in processes, knowledge and skills than in products, services and outputs, which are reinforced by a social and cultural proximity of actors with shared vocabularies, behaviours and values (de la Roca and Puga, 2017; Storper and Venables, 2004; Grabher, 2004; Bishop and Gripaios, 2010; Frenken et al., 2007). These processes underpin the concentration of skills in space and explain why, in the absence of specific mechanisms to bring it about, new high-skilled employment is unlikely to organically move away from existing concentrations of high-skilled workers in major metropolitan centres.

It follows from these assumptions that any high-skill employment growth at the national level will deliver an additional increment of total employment to major metropolitan cities that is not available to smaller regions. Because low- and middleskill employment relativities are held constant, any level of positive high-skilled employment growth will see major metropolitan conurbations achieve higher overall growth rates than smaller regions. This mechanism is illustrated stylistically in Table 1. The employment growth premium available to large metropolitan cities arises from the regional growth differential in the high skill class of employment growth.

\begin{tabular}{|l|c|c|c|c|}
\cline { 2 - 5 } \multicolumn{1}{c|}{} & \multicolumn{4}{c|}{ EMPLOYMENT } \\
\cline { 2 - 5 } \multicolumn{1}{c|}{} & Low Skill & Middle Skill & High Skill & Net Effect \\
\hline National & $\uparrow$ & $\downarrow$ & $\uparrow$ & $\uparrow$ \\
\hline Metropolitan Regions & $\uparrow$ & $\downarrow$ & $\uparrow$ & $\uparrow$ \\
\hline Non-metropolitan Regions & $\uparrow$ & $\downarrow$ & $\downarrow$ & $\downarrow$ \\
\hline
\end{tabular}

TABLE 1: Spatial Unevenness of Job Polarisation

Thus we propose that the job-polarising logic of Baumolian unbalanced growth creates its own logic of regional divergence - a type of geographical unbalanced growth. The more that advanced economies sink into patterns of unbalanced growth, the more these patterns will engender changes in the occupational composition of employment growth. In a manner analogous to Kaldorian cumulative causation (Kaldor, 1970), regions with higher human capital will receive net inflows of high-skilled labour, which lifts the average regional skill level and reinforces the pattern of concentration. Meanwhile, regions with lower-skill concentrations will experience net outflows of high-skill workers and an overall downgrading of the regional skill level. Left unchecked, this dynamic will engender a structural pattern of cumulative regional divergence whereby major metropolitan regions increasingly outperform smaller regions in terms of employment growth.

At its core, our theory of geographical unbalanced growth argues that any notion of economic restructuring must incorporate structural changes in the occupational profile of employment. While it is perhaps reasonable in short-run analyses to focus on changes in industrial composition and treat within-industry occupational changes as marginal, it is clear that the job polarising logic of advanced capitalism can work significant changes on the occupational structure of employment over longer periods. This is not a new insight. The need to link both industry and occupational trends was clear to researchers grappling with the changing geography of employment in post-war America: 
Rather than treating shifts in the occupational structure as a nuisance factor, to be set aside before undertaking comparative mobility analysis, we suggest that shifts in the occupational structure may be both the driving force and the problematic issue in comparative mobility studies. Moreover, if changing occupational mixes affect mobility patterns, students of mobility will want to take more than a casual interest in the sources of occupational transformations (Hauser et al., 1975).

The remainder of the paper approaches our theory of geographical unbalanced growth empirically through an examination of the recent Australian economic record. The Australian case represents an advanced economy that has hitherto attracted minimal interest in the skilled cities and related literature, though a strong tendency toward metropolitan concentration draws parallels to other OECD contexts. In addition, Australia's distinctive metropolitan-regional structure, which is characterised by a small number of large metropolitan centres and many sparsely-populated but geographicallydispersed regions, lends itself to our theoretical framework.

\section{Methodology}

Drawing upon Australian labour force and national accounts data from the last few decades, this paper applies a combination of descriptive statistics and a novel shiftshare framework to assess the proposition that the interaction of industry and skill restructurings is creating the 'metropolising' trend observed across many advanced economies.

A threshold claim is the existence of regional divergence itself. We hypothesise that employment will have grown more strongly in regions within Australia's major metropolitan conurbations than in regions without. To measure this, we develop and employ a novel employment growth indicator, which we call the 'Employment Growth Coefficient' (EGC).

A second claim relates to the existence of 'unbalanced growth.' While space prohibits a thorough empirical examination of Baumolian dynamics in the Australian context, we employ a range of descriptive statistics to establish some of the key trends, consistent with a range of other studies (Storm, 2017; Hartwig and Krämer, 2019; Nordhaus, 2008; Schettkat, 2007; Blien and Sanner, 2006). We hypothesise that most new employment will be captured by lagging industries, and that progressive industries will exhibit weaker aggregate employment growth. We further hypothesise that progressive sector employment growth will be biased toward high-skill occupations, and that new employment in this sector will accrue disproportionately to regions within Australia's major metropolitan conurbations.

We then develop and employ an extended shift-share framework to approach our core theoretical contention that the intertwining of industrial and skill restructurings plays an important role in shaping regional employment trajectories. We hypothesise that changes in the skill structure of employment will better explain regional growth differentials than merely changes in the industry structure. 


\section{Measuring Regional Divergence: the 'Employment Growth Coefficient'}

While it is commonplace to calculate employment change as the percentage growth or, less commonly, the log difference, it is also well-known that simple differencing is sensitive to volatility around the initial and terminal periods. By contrast, our EGC considers all data points in the time-series to represent the magnitude and direction of the trend in regional employment growth over the study period. It is calculated in three steps.

The original time-series is first normalised by indexing the region's data to the initial period. The result is expressed as its natural logarithm to minimise skewness in the distributions. The beta coefficient of an Ordinary Least Squares (OLS) regression is then calculated for each region's normalised time-series, with the period of the timeseries representing the dependent variable. Finally, the beta coefficient is unlogged to convert the coefficient into an interpretable result; namely, the percent change in employment for every unit increase in time.

Interpreting the EGC is straightforward; it represents the average period-toperiod percentage change in regional employment over the study period. For example, if the time-series is of total quarterly hours worked, an EGC of 1.0 would indicate that, in trend terms, the region experienced a one percent increase in hours worked each quarter between 1999 and 2019.

\section{Shift-Share Analysis: the current state of the art}

This paper employs an extended Shift-Share Analysis (SSA) to approach the crux of our argument that the intertwining of industry and skill restructurings shape regional employment growth trajectories.

SSA was originally conceived to measure the extent to which economic restructuring shapes regional variation in socioeconomic performance (Ashby, 1967). The concept of 'economic restructuring' is typically operationalised in these analyses as changes in the industry composition of output. SSA thus starts from the assumption that any observed variation in regional performance could simply reflect changes in the national economic context. After all, if the national economy is generating more jobs in certain industries than in others, it follows that regions specialising in those industries will out-grow regions that do not, all else equal. As national economies undergo structural economic change, these changes will differentially affect regions depending on their industrial structure.

The classical SSA model thus reduces regional changes in some socio-economic variable, often employment, into two components: the effect of changes in the national economic structure, often termed the 'industry mix' effect, and a residual term that captures the combined effect of a range of other factors not immediately discernible in the data (Dinc, 2015; Lahr and Ferreira, 2020). This latter component is often most interesting to researchers as it captures the extent to which the region has out- or under-performed what would be expected given its industrial predisposition. The intent of the residual component is to isolate this exogenous effect to reveal the extent of the region's true endogenous performance (Martin et al., 2016; Clarke et al., 2016; Stimson et al., 2006).

While SSA survives as a popular technique for accounting for patterns of regional variation (Lahr and Ferreira, 2020; Dinc, 2015), it has been subject to criticism since its inception (Cunningham, 1969; Dawson, 1982; Richardson, 1978). The most acute weakness of SSA lies in its classical specification, which fails to unambiguously isolate 
the effect of industry structure from other influences (Artige and van Neuss, 2014). This is a critical flaw as it means that the analyst cannot be confident that the 'industry mix' component captures only the effect of the region's industrial structure on growth outcomes, while the residual captures all other factors.

In an important recent development, Artige and van Neuss (2014) re-specify the classical shift-share model to unambiguously separate-out the industry mix effect from the effect of within-industry changes. ${ }^{\text {ii }}$ The Artige and van Neuss (2014) specification (hereafter, AVN) decomposes the observed difference between a region's growth rate and the nation's growth rate into two effects: Economic Structure (ES) and Competitive Effect (CE).

ES is conceptually equivalent to the 'industry mix' component of the classical model and is interpreted here as a proxy for the regional effects of global and national economic restructuring. CE is conceptually comparable to the residual component of the classical model CE insofar as it reduces to a single measure the myriad of factors that combine to influence a region's performance over-and-above what would be expected had it simply conformed to national patterns.

The AVN equation is as follows:

$$
g_{t+1}^{j}-r_{t+1}=\left[\sum_{i=1}^{I}\left(\omega_{i, t}^{j}-\frac{1}{I}\right) g_{i, t+1}^{j}-\sum_{i=1}^{I}\left(\theta_{i, t}-\frac{1}{I}\right) r_{i, t+1}\right]+\sum_{i=1}^{I} \frac{1}{I}\left(g_{i, t+1}^{j}-r_{i, t+1}\right)
$$

The term on the left-hand side of the equation represents the region-nation growth differential, the first component on the right-hand side represents the Economic Structure effect (ES), the second component on the right-hand side represents the Competitive Effect (CE), and:

$g_{t+1}^{j}$ is employment growth in the $\mathrm{j}^{\text {th }}$ region between the initial and terminal years

$r_{t+1}$ is employment growth in the nation between the initial and terminal years

$\omega_{i, t}^{j}$ is the share of $i^{\text {th }}$ industry in employment of $j^{\text {th }}$ region in the initial year

$\theta_{i, t}$ is the share of $\mathrm{i}^{\text {th }}$ industry in national employment in the initial year, and

$I$ is the number of industries.

\section{Extending SSA to encompass skill restructuring}

The extension proposed here simply incorporates a second dimension (skill) into the conventional AVN framework. This does not require any changes to the AVN equation, but does expand the data requirement.

The extended model uses a three-dimensional matrix of industry, skill and region data, such that a unique employment value can be assigned to each industry-skill-region combination at both the initial and terminal periods. Thus, where the conventional AVN model considers employment in the $i^{\text {th }}$ industry in the $j^{\text {th }}$ region at period $t$, the extended model considers employment in the $i^{\text {th }}$ industry at the $k^{\text {th }}$ skill level in the $j^{\text {th }}$ region at period $t$.

Figure 1 illustrates the concept schematically. 


\section{CONVENTIONAL SSA}

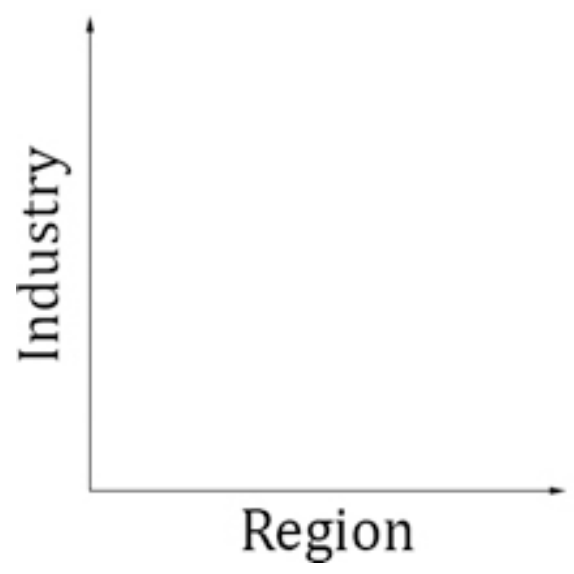

\section{EXTENDED SSA}

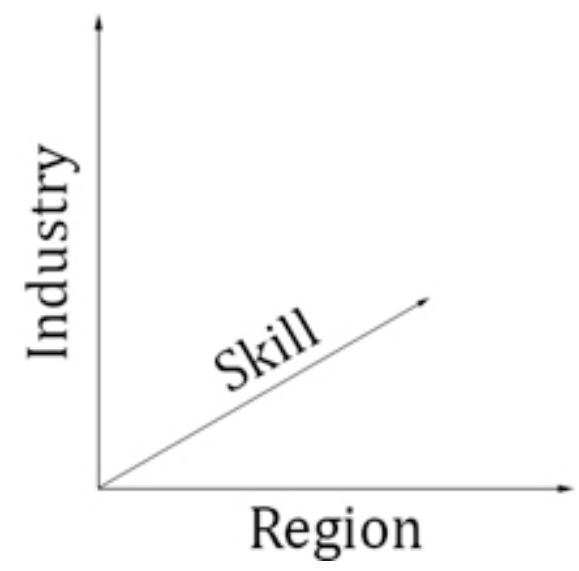

FIGURE 1: Conceptual Frameworks for Conventional and Extended SSA Strategies

Coupling industry and skill in this way has the effect of augmenting the Economic Structure term of the AVN model, ES, with an additional skill dimension. We denote this augmented Economic Structure term, ES'. The extension also excises the influence of any skill restructuring during the study period from $\mathrm{CE}$. We denote this reduced Competitive Effect term, CE'.

CE' can thus be interpreted as a measure of a region's performance over-andabove what would be expected had it conformed to changes at the national level in both the industry and skill composition of employment. The advantage of this approach is that it considers the skill composition of employment as an equally critical dimension of 'economic restructuring' alongside the conventional SSA concept of changes in industry composition.

Data

The data are primarily drawn from the official statistics contained in the Australian National Accounts and Labour Force Survey (ABS, 2019a; 2020a). The extended shift-share analysis draws on the less frequent but more detailed Australian Census for its more detailed data requirement. As a result, the extended SSA analysis covers only a decade (2006-2016), rather than the two-decade period available for the conventional SSA analysis. The Census data are drawn from the microdata provided in the TableBuilder Pro datasets (ABS, 2020b).

Unless otherwise stated, volume measures of employment (rather than headcount), measured at quarterly intervals, are used throughout. Employment data is categorised on the industrial dimension according to the Australian and New Zealand Standard Industrial Classification (ANZSIC) 2006 scheme, while the occupational categorisations follow the Australian and New Zealand Standard Classification of Occupations (ANZSCO) 2013 scheme (ABS, 2013; ABS, 2019b).

Two values for the 'skill' parameter are measured-'high' and 'other.' Highskilled employment is proxied throughout by the 'Professionals' occupational category of the ANZSCO scheme. Professionals is a broad level grouping that captures roles that perform analytical, conceptual and creative tasks typically requiring a Bachelor degree or higher. It captures a range of technical and specialist occupations across business, 
engineering, health, legal and other sectors (ABS, 2019b). This diverse grouping includes some of the fastest growing occupations in the 2006 to 2016 period, including ICT professionals (36\% growth), legal professionals (42\% growth), and design, engineering and transport professionals (26\% growth). iii

Other specifications were considered for the high skill proxy. One alternative is to sum 'Managers' with 'Professionals.' However, 'Managers' defines a much broader class of workers than implied by the theory's notion of 'high skill'-namely, the increasingly technical and specialised skill content associated with more productive production processes (Autor et al., 2003). Many occupations in the 'Managers' category cannot be said to fall into this category, such as those supervising low-skill service work, who constitute $30 \%$ of all Managers. The 'specialist' managers that most closely fit the concept of high-skill used in this paper constitute only half of all Managers (ABS, $2019 b$ ). The available data prohibits the use of these more granular categories at the geographical and industrial scales used in this paper.

The data are spatially organised according to the Australian Statistical Geography Standard (ASGS) 2016, with the Statistical Area Level 4 (SA4) regions serving as the primary unit of analysis. The SA4 structure was chosen for its specific relevance to labour force analysis (ABS, 2016).

The analysis makes use of geographical groupings based around the major metropolitan cities of Sydney, Melbourne, Brisbane and Perth, which are wellestablished focal points for employment growth in Australia (O'Connor et al., 2001; Searle and Pritchard, 2005; Baum et al., 2006). Inspired by Nir's (1990) 'systemic regions' model, we draw a $100 \mathrm{~km}$ geodesic radius around these cities' centres to define four key 'Growth Radii.' The $100 \mathrm{~km}$ perimeter represents a natural commute limit within Australia-91.6\% of employed persons' place of usual residence was within $100 \mathrm{~km}$ of their place of work at the time of the 2016 Australian Census (ABS, 2017). The geography is illustrated in Figure 2. 


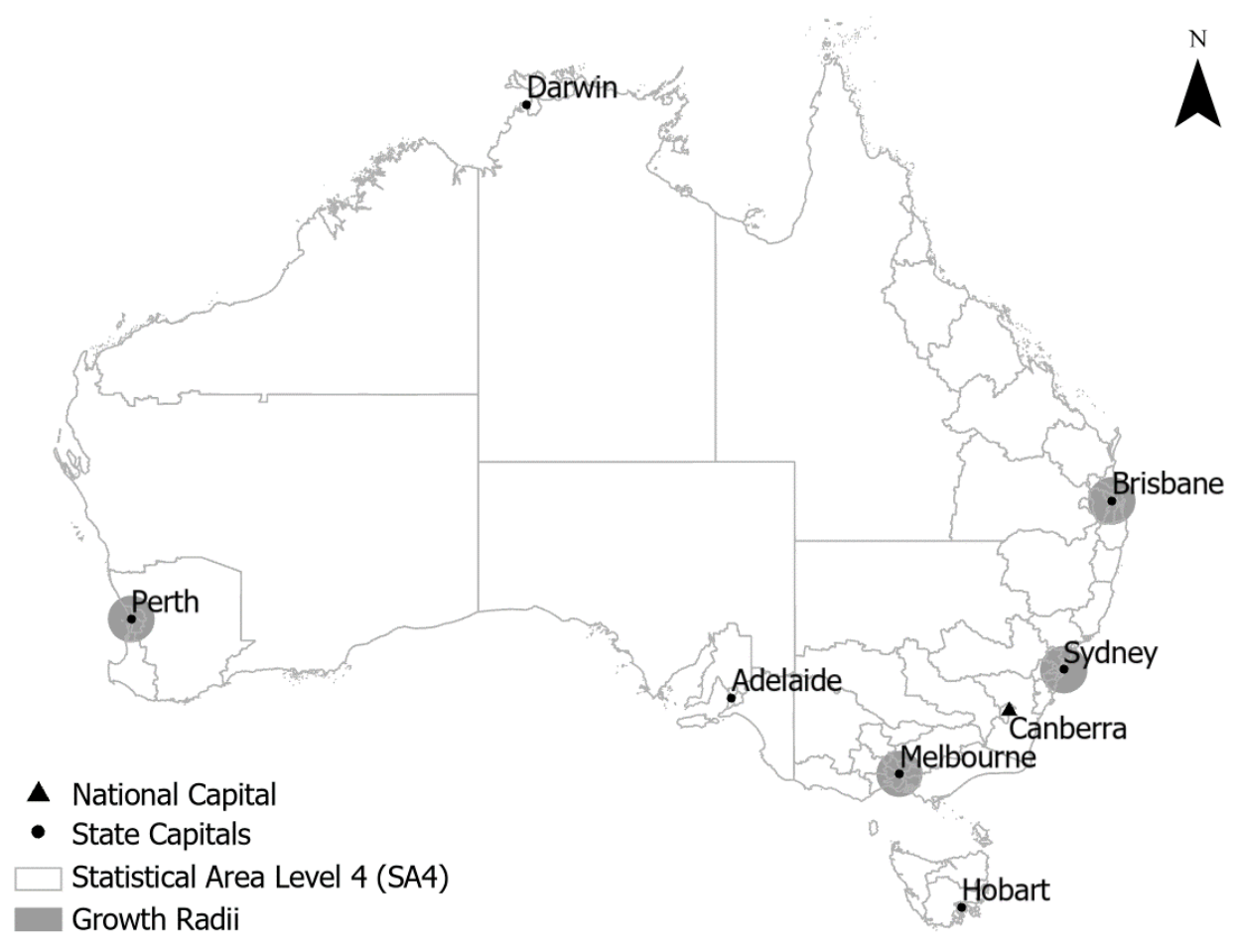

FIGURE 2: Map of Australian Labour Market Geography

Source: The Authors and ABS (2016)

Industry measures of labour productivity are conventionally calculated as the ratio of industry Gross Value Added (GVA) to employment. The 'lagging sector' is defined as those industries exhibiting below-median labour productivity growth for the period 1991-2018, while the progressive sector is defined as those industries exhibiting above-median productivity growth. Productivity growth is defined as the average annual rate of change in labour productivity between 1991 and 2018.

\section{Findings}

The results of the analysis are presented in three sections. First, we present our findings on the question of regional divergence in Australia over recent decades. We then consider the evidence for Baumolian 'unbalanced growth' in the Australian economy. Finally, we present the results of our extended shift-share framework, which examines the extent to which the intertwining of industrial and skill restructurings has shaped regional employment trajectories in recent Australian history.

\section{Regional divergence in Australian employment growth}

The data makes it clear that regional divergence persists as a salient feature of the Australian labourscape. Australian employment recorded an EGC of 0.47 between 1999 and 2019, corresponding to a trend growth rate in aggregate hours worked of just under $2 \%$ per annum. This growth was not shared uniformly across Australia's regions. 
Figure 3 plots the distribution of regional EGC scores for the period. The median EGC of regions within the Growth Radii is more than twice that of regions without $(0.61$ and 0.27 , respectively). This means that employment in the median Growth Radii region grew by almost $2.4 \%$ per annum in trend terms, compared to only $1.0 \%$ percent per annum in non-Growth Radii regions. All but two of the 22 strongest growing regions (top quartile) are located within a Growth Radius, while 17 of the weakest growing regions (bottom quartile) are located outside these growth centres.

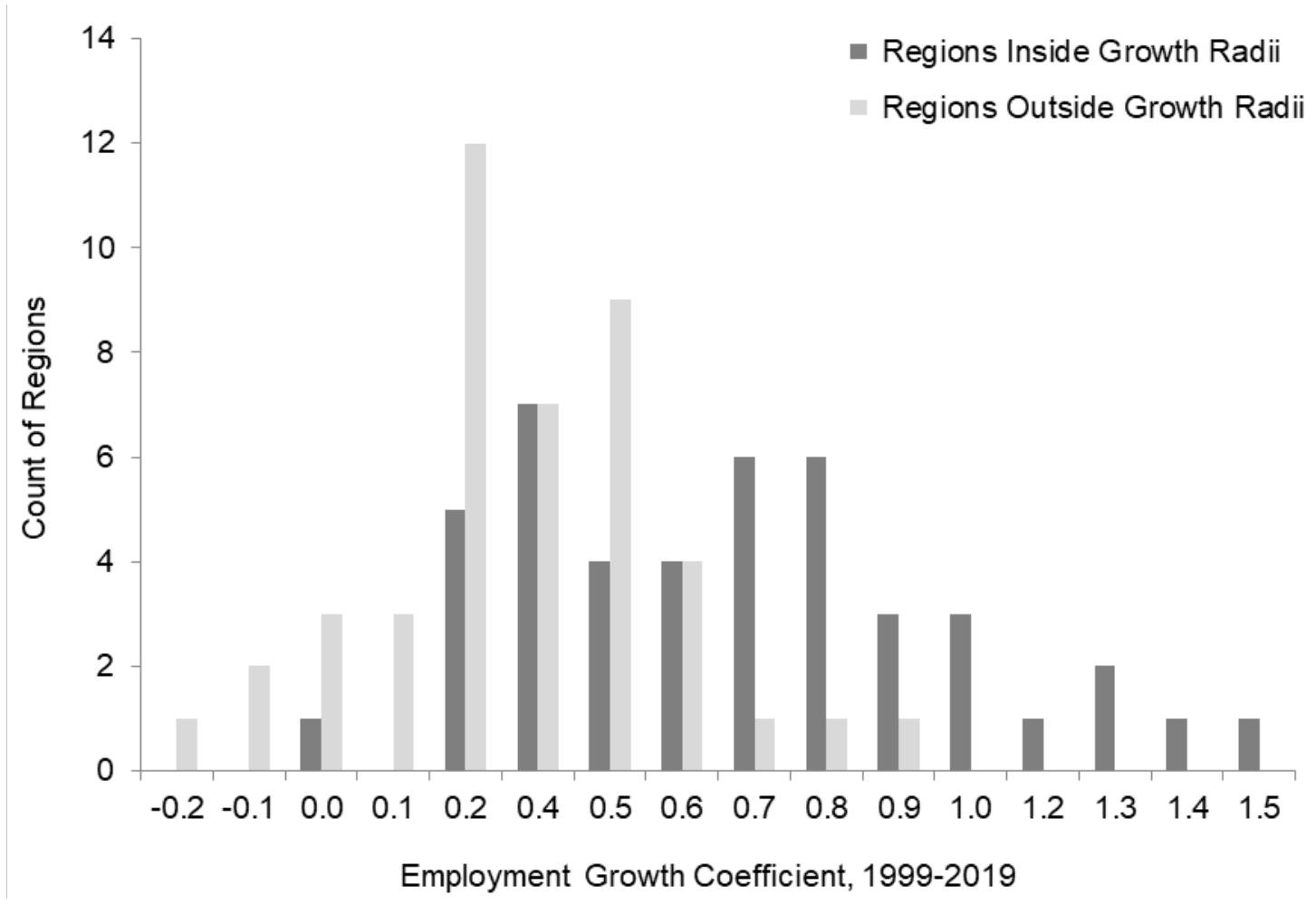

FIGURE 3: Employment Growth Trends, 1999-2019

These stark growth differentials support the thesis that Australian employment growth is favouring the nation's largest metropolitan conurbations. The effect of this has been to produce a pattern of regional divergence whereby Australia's largest metropolitan centres continue to pull away from smaller regions in terms of headline employment.

\section{'Unbalanced Growth' in the Australian economy}

The data supports the proposition that Baumolian unbalanced growth dynamics are operating in the Australian economy. Consistent with Baumol (1967), most new employment has been captured by lagging industries, while progressive industries have grown grow more slowly. The lagging sector commanded less than $40 \%$ of employment in 1991, but captured nearly three-quarters of the total growth over the subsequent three decades.

A disaggregated analysis of industry performance also supports the contention that the lagging sector will come to absorb the majority of new employment. A Spearman's rank order correlation reveals a strong and negative relationship between 
industry-level productivity and employment growth in Australia $(\rho=-0.646, \mathrm{p}=0.003)$, meaning that more productive firms tend to employ relatively fewer new workers.

The data is also consistent with our theory of how Baumolian dynamics would interact with labour market structures to generate spatial unevenness. As expected, employment growth in the progressive sector has been biased toward the higher end of the skill spectrum. The progressive Professional employment share increased by more than $80 \%$, while the non-Professional share decreased by $11 \%$. By comparison, employment shares in the lagging sector for both occupational segments remained virtually unchanged.

Moreover, this skill bias was accompanied by a spatial bias. The progressive sector added $18 \%$ to new employment in the nation's Growth Radii, but subtracted 15\% from total employment in regions outside the Growth Radii. This data is consistent with our theory that occupational skill composition and productivity dynamics are playing important and interconnected roles in differentiating regional growth trajectories.

\section{Geographical Unbalanced Growth - Extended Shift-Share Analysis}

Our extended shift-share framework provides for a more direct measure of the effect of skill-driven occupational restructuring on regional divergence within Australia. We first present the full results of the AVN analysis for a selected region-Illawarra-to illustrate the operation of, and interaction between, the conventional and extended models (Table 2).

Illawarra is a sprawling coastal region of approximately 300,000 residents spread across a land mass of 1,500 $\mathrm{km}^{2}$ south of Sydney. Illawarra's employment growth was weaker than the nation's over the study period, with a growth rate of $12.6 \%$ differential compared to $15.0 \%$ for the nation. This gives a region-nation growth differential of -2.4 percentage points (pp).

The conventional model reveals that the region's industry mix accounts for 4.0 pp of the region-nation growth differential, while the competitive effect contributes -6.5 pp. This means that, based on its industrial structure alone, the region would have outgrown the nation, but other factors have pulled the region below the national benchmark. Another way of looking at this data is to show that the influence of ES on the region-nation differential is 38.4\%. This means the complex of factors captured by CE are significantly more important than industrial restructuring in explaining the region's variation from the national result.

The extended model isolates skill restructuring from this complex of factors by effectively moving its effect into the ES term. This augmented economic structure term, ES', has a much stronger influence on the region-nation differential than the conventional term-60.1\% compared to $38.4 \%$. This means that accounting for changes in both industry and skill increases the explanatory power of economic restructuring by more than $50 \%$ for Illawarra. We can therefore conclude that changes in the occupational composition of employment have been a significant driver of Illawarra's relative employment performance. 


\begin{tabular}{|l|l|r|}
\hline \multicolumn{3}{|c|}{ GROWTH RATES } \\
\hline National Growth & Percent change (\%) & 15.0 \\
\hline Regional Growth & Percent change (\%) & 12.6 \\
\hline Region-Nation Growth Differential & Percentage points (pp) & -2.4 \\
\hline \multicolumn{2}{|c}{ CONVENTIONAL MODEL } \\
\hline Economic Structure (ES) & Percentage points (pp) & 4.0 \\
\hline Economic Structure (ES) & Contribution to change (\%) & 38.4 \\
\hline Competitive Effect (CE) & Percentage points (pp) & -6.5 \\
\hline Competitive Effect (CE) & Contribution to change (\%) & 61.6 \\
\hline & EXTENDED MODEL & -7.3 \\
\hline Economic Structure (ES') & Percentage points (pp) & 60.1 \\
\hline Economic Structure (ES') & Contribution to change (\%) & 4.8 \\
\hline Competitive Effect (CE') & Percentage points (pp) & 39.9 \\
\hline Competitive Effect (CE') & Contribution to change (\%) & \\
\hline
\end{tabular}

TABLE 2: Summary of AVN SSA for Illawarra

Taking a broader view, we find that, on the conventional model, the ES term plays a weaker role than CE in determining region-nation growth differentials across the majority of regions. The median influence of ES is $25 \%$ and the distribution exhibits a distinct positive skew. This means that the changes in industrial composition experienced by Australian regions over time is a relatively weak determinant of employment growth differentials. The majority of variation in employment performance is attributable to regional 'competitive effects' (CE) and thus begs further explanation.

Juxtaposing the results of the conventional and extended models reveals the extent to which skill restructuring is one such factor concealed within the CE term. Figure 4 plots the frequency distributions for both the conventional and extended SSA models. The positive skew evident in the conventional distribution flattens substantially when skill composition is controlled for in the extended model. The median influence of ES rises to 35\% in the extended model (ES'). Thus, for the median region, changes in skill composition increases the explanatory power of economic restructuring by more than a third. 


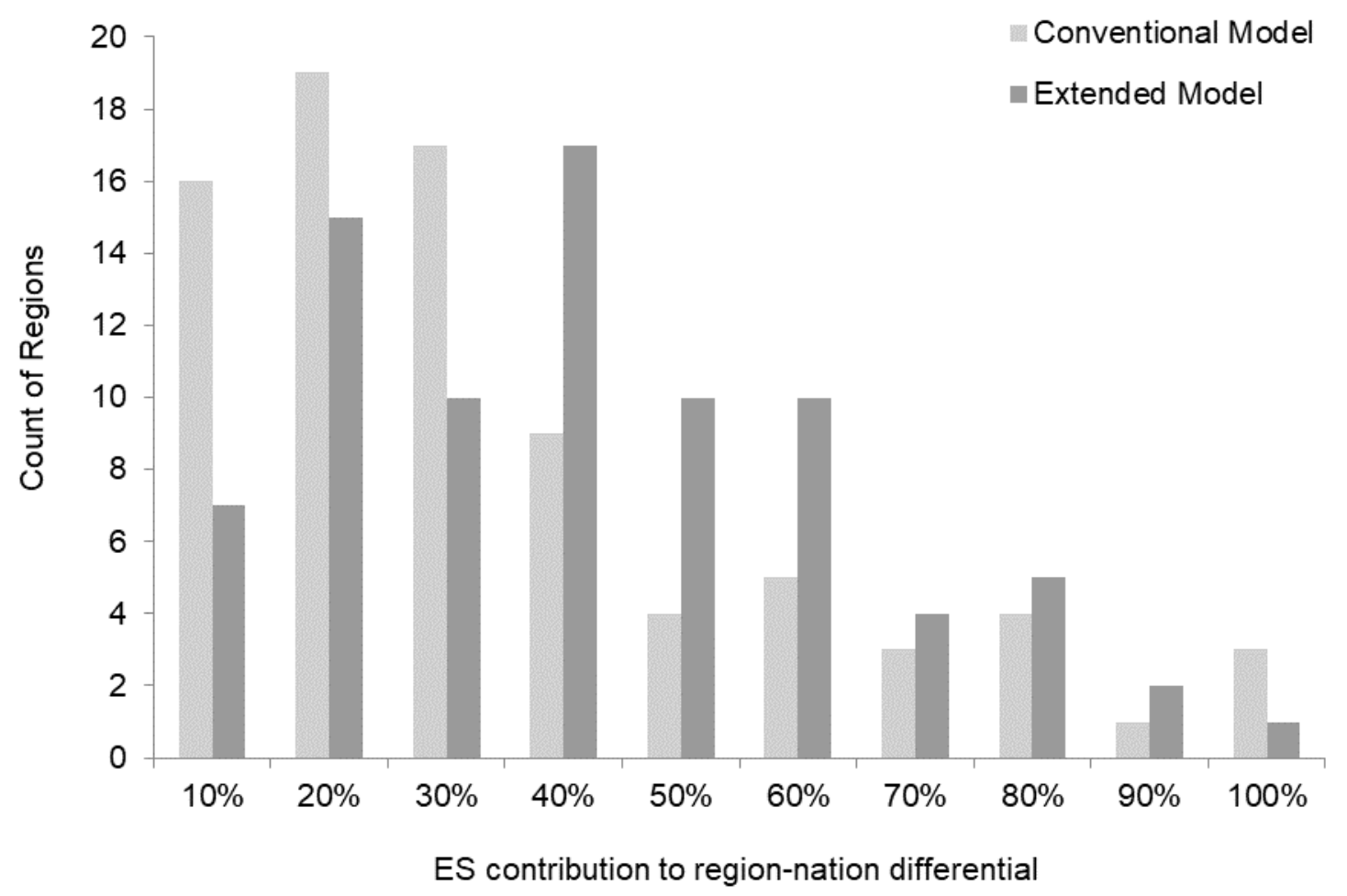

FIGURE 4: Model Comparison of ES Contribution to Region-Nation Growth Differential

Appendix A reports the results of the conventional and extended models for all regions by Growth Radii membership. The results make it clear that Growth Radii regions outperformed other regions in terms of employment growth over the study period. Our extended SSA improves the power of the ES term in explaining this outperformance for the majority (65\%) of the 81 regions analysed. In other words, incorporating the skill dimension improves our understanding of Australian growth differentials in nearly two-thirds of cases. In addition, regions that enjoy some explanatory improvement from the skill dimension tend to be those with higher regionnation growth differentials - the median growth differential for regions where ES' explains more than ES is $-5.5 \mathrm{pp}$, compared to $-2.5 \mathrm{pp}$ for the others. This suggests that the more that regions fall behind the national baseline, the more important the role of skill restructuring.

\section{Conclusion}

This paper has sought to explain the divergent employment growth observed within advanced economies over recent decades by linking Baumol's (1967) theory of unbalanced growth with more contemporary notions of 'job polarisation.' Unbalanced growth theory holds that employment growth will tend to concentrate in less productive industries over time. Job polarisation refers to the widespread observation that low-skilled and high-skilled employment is expanding, while the middle contracts. We have argued that these dynamics intersect to create a particular form of economic restructuring that manifests not only along the industry dimension of employment but also, crucially, the skill dimension.

This paper's main theoretical contribution has been to propose how this particular form of economic restructuring implies a particular form of geographical 
reconfiguration. We have argued that the job-polarising logic of Baumolian unbalanced growth creates its own logic of regional divergence. We theorised that, left unchecked, this process of 'geographical unbalanced growth' engenders a structural pattern of cumulative regional divergence whereby major metropolitan regions increasingly outperform smaller regions in terms of employment growth.

Drawing on recent Australian data, this theoretical framework was evaluated using descriptive statistics and a novel shift-share framework. We found that regional divergence persists in Australia, with a clear 'metropolising' trend emerging from the data (Krätke, 2007). The median Growth Radii region grew by $2.4 \%$ per annum in trend terms, compared to only $1.0 \%$ per annum in the median region outside the Growth Radii.

We also found clear evidence of Baumolian (1967) 'unbalanced growth' in the Australian economy, where the lagging sector captured nearly 75\% of total employment growth since 1991 off a base share of less than 40\%. Consistent with our own theory, employment growth in the progressive sector was found to skew toward both high-skill employment and large metropolitan conurbations. The Professional employment share in the progressive sector increased by more than $80 \%$, while the non-Professional share decreased by $11 \%$. At the same time, the progressive sector added $18 \%$ to total employment within the Growth Radii but subtracted 15\% in regions outside the Growth Radii. These are strong signals that changes in skill composition are deeply implicated with productivity dynamics in driving the metropolisation of recent Australian employment growth.

While this descriptive data provides strong prima facie evidence that industry and skill restructurings interact to drive regional divergence, our extended shift-share framework approaches this link more directly. Despite the relatively short time period analysed (2006-2016), we found a significant skill restructuring effect on region-nation growth differentials. In nearly two-thirds of the 81 regions analysed, our understanding of Australian employment growth differentials was improved when the skill composition of employment was considered alongside changes in industrial composition. For the median region, the skill component accounted for a one-third increase in the explanatory power of economic restructuring.

Taken together, these findings support our theory of geographical unbalanced growth. Consistent with the 'skilled cities' literature, skill-based occupational restructuring emerges as a key problematic in comparative regional analysis. These findings emphasise the need for researchers to take seriously the nexus of industry and skill restructuring in reshaping regional growth trajectories.

The policy implications are also clear: regions that fail to attract a larger share of progressive sector employment growth are likely to continue to lag behind those that succeed. And because progressive sector employment growth so favours high-skilled occupations, the locational density of these occupations will determine regions' ability to attract this growth. Moreover, insofar as unbalanced growth is a structural tendency of advanced capitalism, the problem of regional divergence may have deeper and more systemic roots than commonly thought. In the absence of active and deliberate policy intervention, geographical unbalanced growth implies a continued widening of the gap between regional and metropolitan employment outcomes. This view supports and adds a degree of urgency to suggestions that attracting high-skilled jobs must be a focal point for progressive regional policy (Gabe, 2017; Südekum, 2010; Chadwick et al., 2008). 


\section{References}

ABS (2013) Australian and New Zealand Standard Industrial Classification (ANZSIC), 2006 (Revision 2.0) (cat no. 1292.0), retrieved 30 March 2021: https://www.abs.gov.au/ausstats/abs@.nsf/mf/1292.0

ABS (2016) Australian Statistical Geography Standard (ASGS): Volume 1 - Main Structure and Greater Capital City Statistical Areas, July 2016, (cat no. 1270.0.55.001), retrieved 4 September 2019: http://www.abs.gov.au/ausstats/abs@.nsf/PrimaryMainFeatures/1270.0.55.00 1

ABS (2017) 2016 Census, retrieved 30 March 2021:

https://www.abs.gov.au/websitedbs/censushome.nsf/home/2016

ABS (2019a) Labour Force, Australia, Detailed, Quarterly: Table RQ2. (cat. no. 6291.0.55.003), retrieved 20 June 2019:

https://www.abs.gov.au/statistics/labour/employment-andunemployment/labour-force-australia-detailed-quarterly/latest-release

ABS (2019b) ANZSCO - Australian and New Zealand Standard Classification of Occupations, 2013, Version 1.3 (cat no. 1220.0), retrieved 30 March 2021: https://www.abs.gov.au/AUSSTATS/abs@.nsf/Lookup/1220.0

ABS (2020a) Australian System of National Accounts, 2018-19 (cat no. 5204.0), retrieved 30 October 2020: https://www.abs.gov.au/ausstats/abs@.nsf/PrimaryMainFeatures/5204.0

ABS (2020b) Census TableBuilder Pro Datasets, 2006 and 2016, retrieved 15 December 2020: https://www.abs.gov.au/websitedbs/D3310114.nsf/home/About+TableBuilder

Appelbaum, E. and Schettkat, R. (1994) 'The End of Full Employment? On Economic Development in Industrialized Countries', Intereconomics, May/June, pp. 122-30

Artige, L. and van Neuss, L. (2014) 'A New Shift-Share Method', Growth and Change, 45(4), pp. 667-83

Ashby, D. (1960) “'The shift-share analysis of regional growth": a reply', The Southern Economic Journal, 33, pp. 577-81

Autor, D. and Dorn, D. (2013) 'The Growth of Low-Skill Service Jobs and the Polarization of the U.S. Labor Market', American Economic Review, 103(5), pp. 1553-97

Autor, D., Katz, L. and Kearney, M. (2006) 'The Polarization of the US Labor Market', American Economic Review, 96(2), pp: 189-94

Bárány, Z. and Siegel, C. (2018) 'Job Polarization and Structural Change', American Economic Journal: Macroeconomics, 10(1), pp. 57-89

Barro, R. and Sala-i-Martin, X. (1995) Economic Growth, New York: McGraw-Hill

Baum, S., O'Connor, K. and Stimson, R. (2006) Fault Lines Exposed: Advantage and Disadvantage across Australia 's Settlement System, Melbourne: Monash University ePress

Baumol, W. (1967) “'Macroeconomics of Unbalanced Growth': The Anatomy of Urban Crisis", American Economic Review, 57(3), pp. 415-26

Bell, D. (1973) The Coming of Post-Industrial Society: A Venture in Social Forecasting, New York: Basic Books

Bishop, P. and Gripaios, P. (2010). 'Spatial externalities, relatedness and sector employment growth in Great Britain', Regional Studies, 44, pp: 443-54

Blien, U. and Sanner, H. (2006) 'Structural change and regional employment dynamics', IAB discussion paper, 06-06 
Brakman, S. and C. van Marrewijk (2008) 'It's a big world after all: on the economic impact of location and distance', Cambridge Journal of Regions, Economy and Society, 1(3), pp. 411-37

Chadwick, A., Glasson, J. and Smith, H. (2008) 'Employment Growth in KnowledgeIntensive Business Services in Great Britain during the 1990s - Variations at the Regional and Sub-Regional Level', Local Economy, 23(1), pp. 6-18

Clarke, G., Martin, R. and Tyler, P. (2016) 'Divergent cities? Unequal urban growth and development', Cambridge Journal of Regions, Economy and Society, 9(2), pp. 259-68

Coelli, M. and Borland, J. (2016) 'Job Polarisation and Earnings Inequality in Australia', Economic Record, 92, pp. 1-27

Corliss, M. and Lewis, P. (2014) 'Joblessness, taxable income and regional divergence over time', Economic Papers, 33(3), pp. 263-74

Cunningham, N. (1969) 'A Note on the proper distribution of industry', Oxford Economic Papers, 21(1), pp. 122-27

Dao, M., Das, M., Koczan, Z. and Lian, W. (2017) 'Why is Labor Receiving a Smaller Share of Global Income? Theory and Empirical Evidence', IMF Working Paper, WP $/ 17 / 169$

Dawson, J. (1982) Shift-share analysis: A bibliographic review of technique and applications, Monticello: Dunn, E.S.

de la Roca, J. and Puga, D. (2017) 'Learning by working in big cities', Review of Economic Studies, 84, pp: 106-42

Dinc, M. (2015) Introduction to Regional Economic Development: Major Theories and Basic Analytical Tools, Cheltenham: Edward Elgar

Faggian, A. and McCann, P. (2009) 'Human capital and regional development', in Capello, R. and Nijkamp, P. (eds) Regional growth and development theories in the XXI century: theoretical achievements and future challenges, Cheltenham: Edward Elgar, pp. 133-151

Florida, R. (2017) The New Urban Crisis: Gentrification, Housing Bubbles, Growing Inequality and What We Can Do About It, London: Oneworld

Frenken, K., Van Oort, F. and Verburg, T. (2007) 'Related variety, unrelated variety and regional economic growth', Regional Studies, 41, pp. 685-97

Gabe, T. (2017). The pursuit of economic development: Growing good jobs in U.S. cities and states, Switzerland: Palgrave Macmillan

Gardiner B., Martin R. and Tyler, P. (2013) 'Spatially unbalanced growth in the British economy', Journal of Economic Geography, 13, pp. 889-928

Glaeser, E. (2011) Triumph of the City, London: Macmillan

Glaeser, E. and Berry, C. (2006) 'Why are smart places getting smarter?', Rappaport Institute and Taubman Center Policy Briefs, March

Glaeser, E. and Saiz, A. (2003) 'The rise of the skilled city', NBER Working Paper Series, 10191

Goos, M. and Manning, A. (2007) 'Lousy and Lovely Jobs: The Rising Polarization of Work in Britain', The Review of Economics and Statistics, 89(1), pp: 118-33

Goos, M., Manning, A. and Salomons, A. (2009) 'Job Polarization in Europe', American Economic Review, 99(2), pp: 58-63

Goos, M., Manning, A. and Salomons, A. (2014) “'Explaining Job Polarization”: RoutineBiased Technological Change and Offshoring', American Economic Review, 104(8), pp. 2509-26 
Grabher, G. (2004) 'Learning in Projects, Remembering in Networks?: Communality, Sociality, and Connectivity in Project Ecologies', European Urban and Regional Studies, 11(2), pp: 103-23

Hartwig, J. and Krämer, H. (2019) 'The 'Growth Disease' at 50 - Baumol after Oulton', Structural Change and Economic Dynamics, 51, pp: 463-71

Hauser, R., Koffel, H., Travis, P. and Dickinson, P. (1975) 'Temporal Change in Occupational Mobility: Evidence for Men in the United States', American Sociological Review,

Kaldor, N. (1970) 'The case for regional policies', Scottish Journal of Political Economy, 17 , pp. $337-47$

Krätke, S. (2007) 'The metropolization of the European urban system in the era of globalization', in Taylor et al. (eds.), Cities in globalization: practices, policies and theories, London: Routledge

Krugman, P. (1994) The Age of Diminished Expectations: U.S. Economic Policy in the 1990s, Massachusetts: MIT Press

Lahr, M. and Ferreira, P. (2020) 'A reconnaissance through the history of shiftshare analysis' in Batey, P. (ed.), Handbook of Regional Science, New York: Springer

Martin, P. (2005) 'The geography of inequalities in Europe', Swedish Economic Policy Review, 12, pp. 83-108

Martin, R., Tyler, P., Sunley, P. and Gardiner, B. (2016) 'Divergent cities in post industrial Britain', Cambridge Journal of Regions, Economy and Society, (9), pp. 269-99

McCann, P. (2008), 'Globalization and economic geography: the world is curved, not flat', Cambridge Journal of Regions, Economy and Society, 1(3), pp. 351-70

Moretti, E. (2013) The New Geography of Jobs, Boston: Mariner Books

Neisser, H. (1942) 'Permanent' technological unemployment. Demand for commodities is not demand for labor', American Economic Review, 32, pp. 50-71

Nir, D. (1990) Region as a Socio-environmental System: An Introduction to a Systemic Regional Geography, London: Kluwer Academic Publishers

Nordhaus, W. (2008) “'Baumol's Diseases': A Macroeconomic Perspective”, The B.E. Journal of Macroeconomics, 8(1)

O'Connor, K., Stimson, R. and Daly, M. (2001) Australia's changing economic geography: a society dividing, South Melbourne: Oxford University Press

OECD (2018) OECD Economic Outlook, Issue 2, Paris: OECD

Pike, A., Rodríguez-Pose, A. and Tomaney, J. (2017) Local and Regional Development, London: Routledge

Richardson, H. (1979) Regional Economics, Urbana: University of Illinois Press

Salter, W. (1960) Productivity and Technical Change, Cambridge: Cambridge University Press

Sassen, S. (2001) The Global City: New York, London, Tokyo, Princeton: Princeton University Press

Schettkat, R. (2007) 'The Astonishing Regularity of Service Employment Expansion', Metroeconomica, 58(3), pp. 413-35

Scott, A. (2009) 'Human capital resources and requirements across the metropolitan hierarchy of the USA', Journal of Economic Geography, 9, pp: 207-26

Scott, A. and Storper, M. (2015) “'The nature of cities': the scope and limits of urban theory", International Journal of Urban and Regional Research, 39, pp. 1-15

Searle, G. and Pritchard, B. (2005) “Industry clusters and Sydney's IT sector”: Northern Sydney as 'Australia's Silicon Valley'?', Australian Geographer, 36, pp. 145-69 
Simon, C. (1998) 'Human capital and metropolitan employment growth', Journal of Urban Economics, 43, pp. 223-43.

Simon, C. (2004) 'Industrial reallocation across US cities, 1977-1997', Journal of Urban Economics, 56(1), pp: 119-43

Simon, C. and Nardinelli, C. (2002) 'Human capital and the rise of American cities 19001990', Regional Science and Urban Economics, 32, pp. 59-96

Soja, E. (1980) 'The socio-spatial dialectic', Annals of the Association of American Geographers, 70, pp. 207-25

Sorenson, T. (2000), 'Tilting at Windmills', Policy, 16(2), pp. 8-12

Stimson, R., Stough, R. and Roberts, B. (2006) Regional Economic Development Analysis and Planning Strategy, Berlin: Springer

Storm, S. (2017) “'The New Normal': Demand, Secular Stagnation, and the Vanishing Middle Class", International Journal of Political Economy, 46(4), pp. 169-210

Storper, M. and Scott, A. (2009) 'Rethinking human capital, creativity and urban growth', Journal of Economic Geography, 9(2), pp. 147-67

Storper, M. and Venables, A. (2004) 'Buzz: face-to-face contact and the urban economy', Journal of Economic Geography, 4(4), pp. 351-70

Südekum, J. (2010) 'Human Capital Externalities and Growth of High- and Low-Skilled Jobs', Journal of Economics and Statistics, 230(1), pp.92-114

Sunley, P., Martin, R., Gardiner, B., and Pike, A. (2019) “'In search of the skilled city': Skills and the occupational evolution of British cities”, Urban Studies, April, pp. 125

Weil, D. (2014) The Fissured Workplace: Why Work Became So Bad for So Many and What Can Be Done to Improve It, Cambridge: Harvard University Press 
i Growth in total hours worked for the period 1999 to 2019 for the following occupational grouping: Clerical and Administrative Workers, Community and Personal Service Workers, Labourers, Machinery Operators and Drivers, and Technicians and Trades Workers. Data drawn from ABS (2019a) and analysed at 'Greater Capital City' and 'Rest of State' categories of the Australian Statistical Geography Standard (ABS, 2016).

ii Space prohibits a thoroughgoing comparison of the AVN and classical models. The interested reader is encouraged to review Artige and van Neuss (2014) for a more complete discussion.

iii Growth in total hours worked for the period 1999 to 2019. Data drawn from ABS (2019a). 


\section{APPENDIX A}

TABLE A1: Summary of SSA Results, by Growth Radii membership

\begin{tabular}{|c|c|c|c|c|c|c|c|c|}
\hline \multirow[b]{2}{*}{ Region } & \multirow{2}{*}{$\begin{array}{c}\text { Region } \\
\text { Growth Rate } \\
(\%)\end{array}$} & \multirow{2}{*}{$\begin{array}{l}\text { Region- } \\
\text { Nation } \\
\text { Growth } \\
\text { Differential } \\
(p p)\end{array}$} & \multicolumn{3}{|c|}{ Conventional SSA } & \multicolumn{3}{|c|}{ Extended SSA } \\
\hline & & & ES (pp) & CE (pp) & $\begin{array}{c}\text { ES } \\
\text { Contribution } \\
(\%)\end{array}$ & $E S^{\prime}(p p)$ & CE’ (pp) & $\begin{array}{c}\text { ES' } \\
\text { Contribution } \\
(\%)\end{array}$ \\
\hline \multicolumn{9}{|l|}{ Regions Inside a Growth Radius } \\
\hline Sydney - City and Inner South & 40.0 & 25.0 & 1.4 & 23.6 & 5.6 & 2.8 & 22.2 & 11.3 \\
\hline Sydney - Inner West & 21.4 & 6.4 & 1.7 & 4.7 & 27.1 & 2.3 & 4.1 & 36.5 \\
\hline Sydney - Eastern Suburbs & 14.7 & -0.3 & 3.6 & -4.0 & 47.9 & 6.5 & -6.8 & 48.8 \\
\hline Sydney - Inner South West & 17.6 & 2.6 & -3.3 & 5.9 & 35.8 & -2.9 & 5.5 & 34.6 \\
\hline Sydney - Sutherland & 2.5 & -12.5 & -2.4 & -10.1 & 19.0 & -1.3 & -11.1 & 10.8 \\
\hline Sydney - Outer South West & 16.9 & 1.9 & 1.9 & 0.0 & 98.8 & 0.4 & 1.5 & 20.0 \\
\hline Sydney - South West & 17.0 & 2.0 & -7.9 & 9.9 & 44.4 & -5.0 & 7.0 & 41.8 \\
\hline Sydney - Parramatta & 24.3 & 9.3 & 0.7 & 8.6 & 7.3 & 0.4 & 8.8 & 4.5 \\
\hline $\begin{array}{l}\text { Sydney - Outer West and Blue } \\
\text { Mountains }\end{array}$ & 5.8 & -9.2 & 3.0 & -12.2 & 19.9 & 2.7 & -11.9 & 18.5 \\
\hline Illawarra & 12.6 & -2.4 & 4.0 & -6.5 & 38.4 & -7.3 & 4.8 & 60.1 \\
\hline Sydney - Blacktown & 24.8 & 9.8 & -2.1 & 11.9 & 15.0 & -15.6 & 25.3 & 38.1 \\
\hline Sydney - Ryde & 16.2 & 1.2 & 1.1 & 0.1 & 92.7 & 0.5 & 0.7 & 39.8 \\
\hline $\begin{array}{l}\text { Sydney - Baulkham Hills and } \\
\text { Hawkesbury }\end{array}$ & 9.8 & -5.2 & -1.5 & -3.8 & 28.1 & 0.2 & -5.5 & 3.9 \\
\hline $\begin{array}{l}\text { Sydney - North Sydney and } \\
\text { Hornsby }\end{array}$ & 12.6 & -2.4 & 2.6 & -5.0 & 34.4 & 6.5 & -8.9 & 42.3 \\
\hline Sydney - Northern Beaches & 9.9 & -5.1 & 0.7 & -5.8 & 10.6 & 5.4 & -10.5 & 33.8 \\
\hline Central Coast & 13.5 & -1.5 & 0.2 & -1.7 & 11.8 & 3.8 & -5.3 & 41.8 \\
\hline Melbourne - Inner & 31.8 & 16.7 & -2.1 & 18.9 & 10.1 & -1.4 & 18.1 & 6.9 \\
\hline Melbourne - North West & 25.2 & 10.2 & -7.1 & 17.3 & 29.1 & -12.7 & 22.9 & 35.7 \\
\hline Melbourne - West & 41.1 & 26.1 & -8.6 & 34.7 & 19.9 & -18.8 & 44.9 & 29.5 \\
\hline
\end{tabular}




\begin{tabular}{|c|c|c|c|c|c|c|c|c|}
\hline Melbourne - North East & 23.9 & 8.9 & -4.8 & 13.8 & 26.0 & -8.7 & 17.7 & 33.1 \\
\hline Melbourne - Outer East & 3.0 & -12.0 & -3.3 & -8.7 & 27.7 & -6.4 & -5.6 & 53.5 \\
\hline Melbourne - Inner East & 4.5 & -10.5 & -1.8 & -8.7 & 17.3 & 0.1 & -10.7 & 1.0 \\
\hline Melbourne - Inner South & 12.5 & -2.5 & -5.6 & 3.1 & 64.3 & -5.9 & 3.4 & 63.4 \\
\hline Melbourne - South East & 23.5 & 8.5 & -6.2 & 14.7 & 29.7 & -7.5 & 16.0 & 32.0 \\
\hline Mornington Peninsula & 14.0 & -1.0 & -2.8 & 1.7 & 61.6 & -4.2 & 3.2 & 57.0 \\
\hline Geelong & 20.4 & 5.4 & -3.6 & 9.0 & 28.6 & -13.9 & 19.3 & 41.8 \\
\hline Brisbane - West & 3.3 & -11.7 & 1.1 & -12.8 & 8.0 & 3.7 & -15.5 & 19.4 \\
\hline Brisbane - North & 18.6 & 3.6 & -5.9 & 9.5 & 38.4 & -11.6 & 15.1 & 43.3 \\
\hline Moreton Bay - South & 29.6 & 14.6 & -1.9 & 16.5 & 10.3 & -2.7 & 17.3 & 13.7 \\
\hline Brisbane - East & 13.6 & -1.4 & -4.5 & 3.2 & 58.9 & -7.7 & 6.3 & 54.9 \\
\hline Moreton Bay - North & 20.1 & 5.1 & -7.5 & 12.6 & 37.3 & -4.0 & 9.1 & 30.3 \\
\hline Gold Coast & 26.3 & 11.3 & -6.7 & 18.0 & 27.0 & -10.5 & 21.9 & 32.5 \\
\hline Sunshine Coast & 24.4 & 9.4 & -7.8 & 17.2 & 31.3 & -7.4 & 16.8 & 30.7 \\
\hline Toowoomba & 10.6 & -4.4 & -6.3 & 1.9 & 76.8 & -13.9 & 9.5 & 59.4 \\
\hline Perth - Inner & 19.7 & 4.7 & 2.6 & 2.1 & 55.5 & 5.4 & -0.8 & 87.3 \\
\hline Perth - North West & 21.5 & 6.5 & 1.9 & 4.6 & 29.0 & 2.3 & 4.2 & 35.7 \\
\hline Perth - North East & 23.4 & 8.4 & 0.6 & 7.8 & 7.0 & 1.0 & 7.4 & 11.5 \\
\hline Perth - South East & 20.8 & 5.8 & 0.7 & 5.0 & 13.0 & -0.8 & 6.6 & 10.9 \\
\hline Perth - South West & 28.3 & 13.3 & 0.1 & 13.2 & 0.8 & 1.1 & 12.2 & 8.0 \\
\hline Mandurah & 43.7 & 28.7 & -0.4 & 29.0 & 1.2 & -6.8 & 35.5 & 16.1 \\
\hline \multicolumn{9}{|l|}{ Regions Outside a Growth Radius } \\
\hline New South Wales - Central West & 4.9 & -10.1 & 1.0 & -11.1 & 8.4 & -1.5 & -8.7 & 14.4 \\
\hline Hunter Valley exc Newcastle & 15.2 & 0.2 & 3.9 & -3.6 & 51.6 & 5.6 & -5.3 & 51.1 \\
\hline Newcastle and Lake Macquarie & 12.0 & -3.0 & 2.9 & -5.9 & 33.1 & 3.1 & -6.1 & 33.8 \\
\hline Mid North Coast & 9.1 & -5.9 & 3.0 & -8.9 & 25.4 & 1.7 & -7.5 & 18.2 \\
\hline $\begin{array}{l}\text { Southern Highlands and } \\
\text { Shoalhaven }\end{array}$ & 13.3 & -1.7 & 3.8 & -5.5 & 40.6 & 8.0 & -9.8 & 45.1 \\
\hline Capital Region & 9.2 & -5.8 & -0.3 & -5.5 & 5.2 & 2.7 & -8.5 & 24.0 \\
\hline Richmond - Tweed & 9.4 & -5.6 & -3.0 & -2.6 & 53.5 & -2.1 & -3.5 & 38.0 \\
\hline Coffs Harbour - Grafton & 8.9 & -6.1 & -1.6 & -4.6 & 25.6 & -12.6 & 6.5 & 66.0 \\
\hline
\end{tabular}




\begin{tabular}{|c|c|c|c|c|c|c|c|c|}
\hline New England and North West & 3.1 & -11.9 & -11.8 & -0.2 & 98.5 & -9.9 & -2.1 & 82.6 \\
\hline Far West and Orana & -2.2 & -17.2 & 4.1 & -21.3 & 16.2 & 3.1 & -20.3 & 13.2 \\
\hline Queensland - Outback & -7.6 & -22.6 & -2.5 & -20.1 & 11.0 & -10.3 & -12.3 & 45.5 \\
\hline Darling Downs - Maranoa & 2.5 & -12.5 & -9.0 & -3.4 & 72.3 & -39.4 & 26.9 & 59.4 \\
\hline Riverina & 2.5 & -12.5 & -1.2 & -11.2 & 9.9 & -9.3 & -3.2 & 74.4 \\
\hline Murray & -1.5 & -16.5 & -1.5 & -15.0 & 9.3 & -1.0 & -15.6 & 5.8 \\
\hline Hume & 4.4 & -10.6 & -3.9 & -6.7 & 36.8 & -8.0 & -2.6 & 75.7 \\
\hline Warrnambool and South West & -0.5 & -15.5 & 2.2 & -17.7 & 11.1 & -3.9 & -11.6 & 25.4 \\
\hline Ballarat & 14.0 & -1.0 & -0.8 & -0.2 & 78.7 & -5.0 & 4.0 & 55.8 \\
\hline Victoria - North West & -4.0 & -19.0 & -1.5 & -17.5 & 7.7 & -7.1 & -11.9 & 37.6 \\
\hline Bendigo & 14.1 & -1.0 & -0.1 & -0.8 & 13.1 & -4.2 & 3.2 & 56.4 \\
\hline Shepparton & 0.8 & -14.2 & -5.0 & -9.2 & 35.3 & -924.8 & 910.6 & 50.4 \\
\hline Latrobe - Gippsland & 9.2 & -5.8 & 2.3 & -8.1 & 21.8 & -1.3 & -4.5 & 22.3 \\
\hline Wide Bay & 5.2 & -9.8 & -0.3 & -9.5 & 3.0 & 1.9 & -11.7 & 13.9 \\
\hline Central Queensland & 7.5 & -7.6 & 2.7 & -10.2 & 20.7 & 5.6 & -13.2 & 29.9 \\
\hline Mackay - Isaac - Whitsunday & 6.4 & -8.6 & 2.0 & -10.6 & 15.8 & 5.0 & -13.6 & 26.9 \\
\hline Cairns & 9.9 & -5.1 & 3.5 & -8.6 & 29.0 & 1.9 & -6.9 & 21.2 \\
\hline Adelaide - North & 10.2 & -4.8 & -3.4 & -1.4 & 71.1 & -2.2 & -2.7 & 45.1 \\
\hline Adelaide - West & 14.8 & -0.2 & -2.7 & 2.5 & 52.2 & -1.5 & 1.3 & 54.1 \\
\hline Adelaide - Central and Hills & 5.0 & -10.0 & 1.9 & -11.9 & 13.7 & 4.6 & -14.6 & 24.0 \\
\hline Adelaide - South & 5.5 & -9.5 & 0.1 & -9.6 & 1.5 & 2.5 & -12.0 & 17.3 \\
\hline South Australia - South East & 2.0 & -13.0 & -5.4 & -7.6 & 41.9 & -13.1 & 0.1 & 99.4 \\
\hline Barossa - Yorke - Mid North & 5.3 & -9.7 & -2.3 & -7.4 & 24.1 & -16.3 & 6.6 & 71.1 \\
\hline South Australia - Outback & -3.4 & -18.4 & 1.5 & -19.9 & 6.8 & -7.5 & -10.9 & 40.8 \\
\hline Western Australia - Wheat Belt & 2.9 & -12.1 & -8.3 & -3.8 & 68.8 & -20.8 & 8.7 & 70.4 \\
\hline Bunbury & 18.9 & 3.8 & -1.9 & 5.7 & 24.7 & -2.7 & 6.5 & 29.0 \\
\hline Western Australia - Outback (North) & 3.7 & -11.3 & 3.6 & -14.9 & 19.5 & -4.2 & -7.0 & 37.5 \\
\hline $\begin{array}{l}\text { Western Australia - Outback } \\
\text { (South) }\end{array}$ & 40.1 & 25.1 & 4.7 & 20.3 & 18.9 & -1.1 & 26.2 & 4.0 \\
\hline Northern Territory - Outback & -4.2 & -19.2 & -3.9 & -15.3 & 20.2 & -26.8 & 7.6 & 77.9 \\
\hline Hobart & 9.1 & -6.0 & 0.9 & -6.8 & 11.2 & 6.1 & -12.0 & 33.5 \\
\hline Tasmania - South East & 6.7 & -8.3 & -7.0 & -1.4 & 83.7 & -19.1 & 10.7 & 64.0 \\
\hline
\end{tabular}


Launceston and North East

Tasmania - West and North West
$1.4 \quad-13.6$

$\begin{array}{ll}0.3 & -14.7\end{array}$

1.1

$-0.5$
$-14.7$

$-14.2$

\begin{tabular}{l|}
7.0 \\
3.7
\end{tabular}

2.0

$-2.9$ 